\title{
Methods for Collecting Milk from Mice
}

\author{
Edward J. DePeters • Russell C. Hovey
}

Received: 4 November 2009 / Accepted: 6 November 2009 / Published online: 24 November 2009

(C) The Author(s) 2009. This article is published with open access at Springerlink.com

\begin{abstract}
Mouse models offer unique opportunities to study mammary gland biology and lactation. Phenotypes within the mammary glands, especially those caused by genetic modification, often arise during lactation, and their study requires the collection of adequate volumes of milk. We describe two approaches for collecting milk from lactating mice. Both methods are inexpensive, are easy to use in the laboratory or classroom, are non-invasive, and yield adequate volumes of milk for subsequent analyses.
\end{abstract}

Keywords Lactation · Mouse · Milking

Abbreviations
$\begin{array}{ll}\text { ID } & \text { inside diameter } \\ \text { OD } & \text { outside diameter } \\ \text { SDS-PAGE } & \begin{array}{l}\text { sodium dodecyl sulfate polyacrylamide gel } \\ \text { electrophoresis }\end{array}\end{array}$

\section{Introduction}

Mice are widely-used to study the impacts of genetics and environment on the mammary gland, including their roles in mammary cancer. The widespread utilization of genetically-modified mice to study mammary gland biology has often yielded phenotypes related to lactation [5-7]. The utility of individual milk samples collected from mice was sometimes complicated by a small sample volume, which impacted the reliability of chemical analyses [4]. In other situations the acquisition of sufficient milk volume required the mouse to be euthanized [2]. Rodgers [10] described a

\section{E. J. DePeters $\cdot$ R. C. Hovey $(\varangle)$}

Department of Animal Science, University of California, Davis,

2145 Meyer Hall, One Shields Avenue,

Davis, CA 95616, USA

e-mail: rchovey@ucdavis.edu milking system to collect milk from rats. This elegant milking system was also used with mice [4]. Using a less complicated method of milking, sufficient quantities of milk were obtained to study fatty acid synthesis in the mammary glands of transgenic mice $[6,7]$. Here we summarize two simple methods to collect milk from lactating mice. In both cases, the equipment required is simple, easy to construct, and allows for the assembly of multiple milking devices to collect milk from a large number of mice at one time. Collecting milk from mice also presents a unique teaching opportunity for students of the sciences. In this regard, mice are cheaper and easier to use compared with ruminants (cattle, sheep, and goats) and afford a direct experience to more students.

\section{Methods}

General

Two different methods have been used in the classroom and for research at UC Davis. Both methods were approved by the UC Davis Institutional Animal Care and Use Committee. For both methods the dam and her litter are separated for approximately $2 \mathrm{~h}$ prior to milking. Pups can be maintained in a warm nest environment during this time. Intraperitoneal injection of mice is performed as described previously $[1,8]$. Each mouse receives $0.1 \mathrm{ml}$ (2 IU) of oxytocin intraperitoneally using a 27-guage needle attached to a $1 \mathrm{ml}$ syringe. Milking should be initiated within 1 min after the administration of oxytocin, a 9 amino acid peptide with an extremely short half-life. A second injection of oxytocin may also be called for after a few minutes. While oxytocin is generally administered intraperitoneally, its small molecular size means it is also effective if given subcutaneously. Oxytocin is readily acquired by veterinary prescription. 
Several factors will affect milk yield. Yields will be optimal in the first 1-2 weeks of lactation and can decline substantially towards the end of the 3rd week as pups begin to consume solid food. Milk yield will also differ across strains, and increases with parity. Furthermore, stress will negatively affect yield.

\section{Method 1}

The first method utilizes manually-generated vacuum to aspirate milk from the mammary glands of each mouse through the teat (Fig. 1a). The milking device consists of a Pasteur pipette flamed lightly at the end to reduce the orifice diameter and smooth any sharp edges. The ID of the orifice should be approximately $0.75 \mathrm{~mm}$. Gentle aspiration is applied using a pipette bulb along with pulses of "sucking". After several pulses milk should be visible within the teat. Several additional pulses may be needed to evacuate milk via the teat sphincter, where gentle elongation of the teat while it is under vacuum may help. Gentle manual stimulation at the base of the teat may also improve the letdown of milk from the teat. Milk should move into the pipette after continued application of pulsed vacuum. Where possible all the collected milk should be ejected into a capped tube at once so as to avoid transfer losses. This method consistently yields approximately $20 \mu \mathrm{l}$ per gland. This approach often is most successful when performed by two people - one to restrain the mouse while the other collects the milk.

\section{Method 2}

The milking unit (Fig. 1b and 1c) was used previously at UC Davis by others (G.B. Anderson) and has been modified to meet research needs and the design of laboratory utilities. The milking system consists of tubing and a $1.5 \mathrm{ml}$ centrifuge tube. Starting at the vacuum source there is a $9 \mathrm{~cm}$ section of Tygon tubing (9/16 in. OD, 5/16 in. ID, $1 / 8$ in. wall) that connects to house vacuum. This section connects to an $11 \mathrm{~cm}$ piece of Tygon tubing (3/8 in.
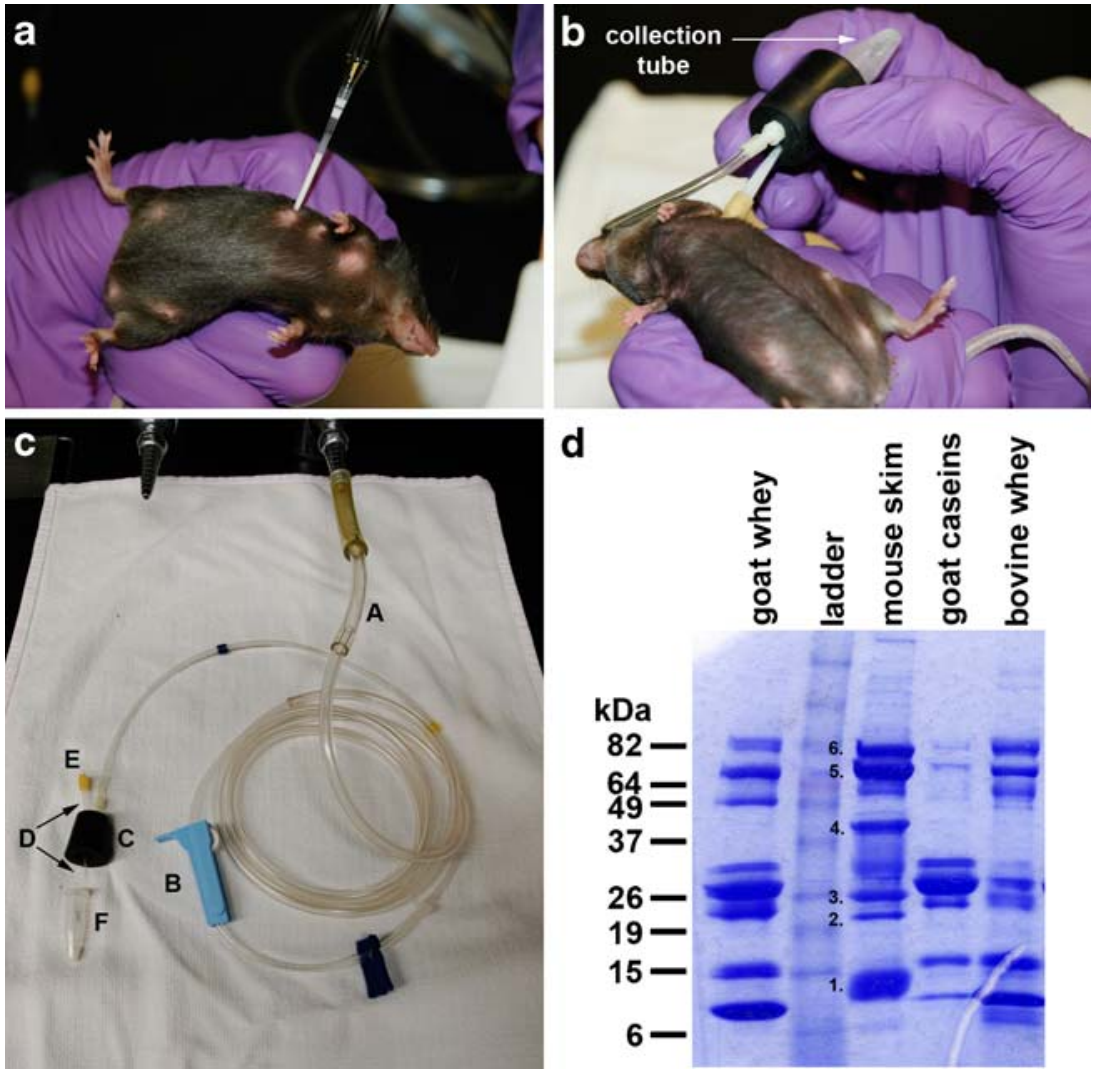

d

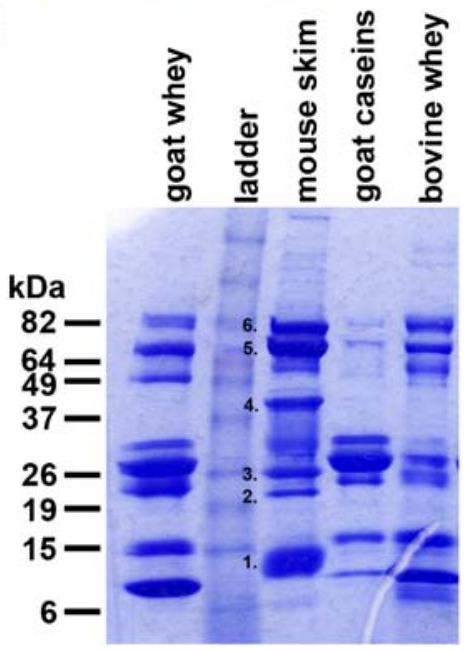

Figure 1 Mouse milking procedures. a Method 1 showing milk being drawn into the Pasteur pipette from the right thoracic \#3 mammary gland. b Mouse being milked using Method 2. The soft latex tubing is positioned over the teat, with milk being collected into the collection tube. c Apparatus used in Method 2. A, Tygon tubing connected to house vacuum, progressively stepped down in size, $B$ roller clamp, $C$ rubber stopper connected to tubing via connector, and bored to receive the $1.5 \mathrm{ml}$ centrifuge tube, $D$ Multiflex tip penetrating rubber stopper,

$E$ latex teat cup, $F 1.5 \mathrm{ml}$ centrifuge tube. The dark blue clamp (bottom center) is an optional vacuum cut-off. d Coomassie bluestained SDS-PAGE analysis of milks from different species and their crude fractions, as prepared by undergraduate students. The predicted proteins detected in mouse milk (as described by Boumahrou et al. [2]) are 1. whey acidic protein, 2. $\gamma$-casein, 3. $\beta$-casein, 4. $\alpha$ s1-casein, 5. serum albumin, 6 . lactoferrin. 
OD, 1/4 in. ID, 1/16 in. wall) that reduces tubing diameter, followed by $152 \mathrm{~cm}$ of Tygon tubing (1/4 in. OD, 1/8 in. ID, $1 / 16$ in. wall). Diameter is reduced further by a $30 \mathrm{~cm}$ section of Tygon tubing (1/8 in. OD, 1/16 in. ID, 1/32 in. wall), with a roller clamp to regulate vacuum. Tubing sections up to this point can be fused together with a small drop of cyclohexanone applied to each junction. Finally, a $42 \mathrm{~cm}$ section of tubing (1/8 in. OD, 1/16 in. ID, 1/32 in. wall) is joined via a tubing connector. All tubing lengths are modifiable. If milk accidentally enters the vacuum line, it can easily be changed at this point so the next sample does not become contaminated. A hard plastic connector penetrates the stopper (Vacutainer-tube stopper, or \#3 rubber stopper bored out on the topside), that receives the $1.5 \mathrm{ml}$ centrifuge tube which collects the milk. A Multiflex tip is also passed through the stopper by making a small hole using an 18 gauge needle. This tip drains into the collecting tube under negative pressure. Finally a short $(\sim 8 \mathrm{~mm})$ piece of soft, flexible latex tubing is added across the wide end of the Multiflex tip; this is the tubing that will be placed onto the teat of the mouse. The negative pressure within the Tygon tubing draws milk into the collection tube.

\section{Teaching Exercises}

Mice were used to determine the effect of diet on the fatty acid composition of milk lipids. The responses to two diets that contained either an unsaturated lipid or a saturated lipid in a commercially purchased diet (Table 1) were compared. Students were involved with the feeding and weighing of dams and their pups, and milking the dams. Fatty acid composition of the milk lipid was performed for the

Table 1 Composition of selected fatty acids in two different diets fed to mice for the teaching exercise.

\begin{tabular}{lcr}
\hline Fatty acid & Unsaturated diet & Saturated diet \\
\hline C14:0 & 0.78 & 2.00 \\
C16:0 & 16.00 & $\mathbf{2 6 . 1 3}$ \\
C16:1 trans & 0.02 & 0.13 \\
C16:1 cis & 1.09 & 1.37 \\
C17:0 & 0.20 & 0.94 \\
C18:0 & 5.26 & $\mathbf{2 6 . 9 9}$ \\
C18:1 trans 10 & 0.09 & 0.59 \\
C18:1 cis $9 \& 10$ & $\mathbf{2 6 . 5 2}$ & 16.95 \\
C18:2 n6 & $\mathbf{4 2 . 0 6}$ & 16.28 \\
C18:3 n3 & 1.91 & 1.42 \\
C20:4 & 0.19 & 0.18 \\
C22:6 n3 & 0.44 & 0.41 \\
\hline
\end{tabular}

Bold values indicate major differences in the fatty acid profiles of the 2 diets.
Table 2 Composition ( $\mathrm{mg} / 100 \mathrm{mg}$ fatty acid) of selected fatty acids in milk from mice fed a diet containing supplemental saturated or unsaturated lipid.

\begin{tabular}{lcc}
\hline Fatty acid & Unsaturated diet & Saturated diet \\
\hline C4-C10 & 3.74 & 3.33 \\
C12:0 & 4.95 & 5.14 \\
C14:0 & $\mathbf{6 . 6 7}$ & $\mathbf{8 . 1 5}$ \\
C16:0 & $\mathbf{2 1 . 7 3}$ & $\mathbf{2 8 . 1 8}$ \\
C18:0 & 5.10 & $\mathbf{6 . 8 1}$ \\
C18:1 cis 9 & 20.63 & $\mathbf{2 3 . 1 6}$ \\
C18:2 & $\mathbf{2 6 . 6 7}$ & 12.32 \\
C18:3 & 1.66 & 1.76 \\
C20:4 & 0.66 & 0.46 \\
C22:5 & 0.13 & 0.12 \\
C22:6 & 0.53 & 0.36 \\
C18:1 trans & 0.18 & $\mathbf{0 . 5 9}$ \\
\hline
\end{tabular}

Bold values indicate the major differences in the fatty acid profiles of milk from the dietary groups, indicating how milk lipid composition reflects dietary intake.

students using methods described previously for bovine milk [3]. The fatty acid composition of the milk lipids reflected the fatty acid composition of the diet (Table 2). These data supported the material presented in lectures on comparative lipid digestion and metabolism in nonruminants and ruminants, where the polyunsaturated fatty acid composition of milk lipids from ruminants does not reflect the diet because of biohydrogenation of unsaturated fatty acids in the reticulo-rumen by anaerobic microorganisms whereas the fatty acid composition of milk lipids in nonruminants does reflect the fatty acid composition of the diet.

In a separate class students used milk they collected from mice using Method 1 to compare its protein composition with milk from other species (cow, goat) and partial fractions that they prepared from cow and goat milk. Students resolved their samples (10 $\mu \mathrm{l}$ of mouse milk) on SDS-PAGE and initiated the Coomassie staining using a microwave-based staining approach that allowed for rapid visualization of protein bands [9]. Destaining continued overnight prior to drying of the gel for analysis by students. The resulting gel highlighted the different abundance of major milk proteins and their migration through SDSPAGE (Fig. 1d).

\section{Summary}

Two methods are presented to enable the collection of milk from mice for studying aspects of lactation and mammary gland biology. Both systems are easy to make and inexpensive. Multiple units can be made so that large numbers of mice can be milked at one time, and both 
milking systems are gentle to the animal and have no effect of the lactating mouse or her pups. The choice of method will largely reflect the volume of milk required for subsequent analyses and operator comfort. Method 1 yields smaller volumes that are adequate for individual assays such as SDS-PAGE or western blotting. Method 2 allows for the collection of larger volumes for analyzing multiple components or lipid extraction, fatty acid methylation, and fatty acid determination using methods for bovine lipids [3]. Both milking systems are readily adaptable for the teaching laboratory given their ease of construction and use.

Open Access This article is distributed under the terms of the Creative Commons Attribution Noncommercial License which permits any noncommercial use, distribution, and reproduction in any medium, provided the original author(s) and source are credited.

\section{References}

1. Arioli V, Rossi E. Errors related to different techniques of intraperitoneal injection in mice. Appl Microbiol. 1970;19 (704):705.
2. Boumahrou N, Andrei S, Miranda G, Henry C, Panthier JJ, Martin P, et al. The major protein fraction of mouse milk revisited using proven proteomic tools. J Physiol Pharmacol. 2009;60(Suppl. 2):113-8.

3. DePeters EJ, German JB, Taylor SJ, Essex ST, Perez-Monti H, et al. Fatty acid and triglyceride composition of milk fat from lactating Holstein cows in response to supplemental canola oil. J Dairy Sci. 2001;84:929-36.

4. Gors S, Kucia M, Langhammer M, Junghans P, Metges CC. Technical note: milk composition in mice-methodological aspects and effects of mouse strain and lactation day. J Dairy Sci. 2009;92:632-7.

5. Houdebine LM. Expresssion de proteins recombinantesdans le lait d'animaux transgeniques. Rev Fr Transfus Hemobiol. 1993;36:49-72.

6. Kao BT, DePeters EJ, Van Eenennaam AL. Mice raised on milk transgenically enriched with n-3 PUFA have increased brain docosahexaenoic acid. Lipids. 2006a;41:543-9.

7. Kao BT, Lewis KA, DePeters EJ, Van Eenennaam AL. Endogenous production and elevated levels of long-chain n-3 fatty acids in the milk of transgenic mice. J Dairy Sci. 2006b;89:3195-201.

8. Miner NA, Korhler J, Greenaway L. Intraperitoneal injection of mice. Appl Microbiol. 1969;17:250-1.

9. Nesatyy VJ, Dacanay A, Kelly JF, Ross NW. Microwave-assisted protein staining: mass spectrometry compatible methods for rapid protein visualization. Rapid Commun Mass Spectrom. 2002;16: 272-80.

10. Rodgers CT. Practical aspects of milk collection in the rat. Lab Anim. 1995;29:450-5. 